\title{
Mucopolysaccharide transformation by sulfide in diatom cultures and natural mucilage
}

\author{
I. Ciglenečki ${ }^{1, *}$, M. Plavší́ ${ }^{1}$, V. Vojvodić ${ }^{1}$, B. Ćosovići ${ }^{1}$, M. Pepi ${ }^{2}$, F. Baldi ${ }^{2}$ \\ ${ }^{1}$ Center for Marine and Environmental Research, Rudjer Bošković Institute, Bijenička 54, 10000 Zagreb, Croatia \\ ${ }^{2}$ Department of Environmental Sciences, Cà Foscari University, Calle Larga S. Marta, Dorsoduro 2137, Venezia 30121, Italy
}

\begin{abstract}
The role of sulfur species in the formation and stability of mucus in the Adriatic Sea was studied in natural aggregates and in a mixed diatom culture. Benthic diatoms were isolated from a sample collected from the sea bottom in the northern Adriatic Sea, cultivated in $\mathrm{f} / 2$ medium at room temperature, and irradiated with dim light (30 to $\left.40 \mu \mathrm{mol} \mathrm{m}^{-2} \mathrm{~s}^{-1}\right)$. Subcultures were incubated at room temperature under anaerobic conditions with different concentrations of sulfide $\left(10^{-4}\right.$ and $\left.10^{-3} \mathrm{~mol}^{-1}\right)$ for up to $1 \mathrm{mo}$. Interactions between sulfide and organic matter in the cultures were followed for $10 \mathrm{~d}$ through: (1) formation of organosulfur species; (2) changes in surfactant activity; (3) degradation of pennate diatoms followed by cell lysis and release of large amount of polysaccharides. Dissolved organic carbon (DOC) concentration increased from $7.17 \mathrm{mg} \mathrm{l}^{-1}$ in the ambient water of untreated diatom cultures to $40 \mathrm{mg} \mathrm{l}^{-1}$ in sulfide-treated samples. Surfactant activity increased by 2 orders of magnitude in the same sulfide-treated samples (both ambient water and aggregates of enriched diatom cultures). The concentration of surface-active substances (SAS, expressed as Triton-X-100 concentration) increased from $0.35 \mathrm{mg} \mathrm{l}^{-1}$ in the aggregate and $0.59 \mathrm{mg} \mathrm{l}^{-1}$ in the ambient water of the untreated diatom cultures to $20 \mathrm{mg} \mathrm{l}^{-1}$ in sulfide-incubated samples. Epifluorescence microscopy showed that diatoms decomposed under sulfide treatment; a specific molecular probe for glucose and mannose (Con-A lectin conjugated by fluorescein) showed that decomposing diatoms released large amounts of polysaccharides. These experiments indicate that massive diatom lysis in bottom or anoxic microzones is one of the factors triggering mucilage formation in the Adriatic Sea, and reduced sulfur species due to microbial activity play an important role in the formation and stability of mucilage development.
\end{abstract}

KEY WORDS: Mucilage · Benthic diatoms · Con-A lectin · Microscopy · Adriatic Sea · Anoxia · Reduced sulfur species $\cdot$ Voltammetry

\section{INTRODUCTION}

The appearance of mucilage in the Adriatic Sea has been observed periodically since 1800, with major mucus blooms during the 1990s. Mucilaginous algal blooms are also becoming more frequent in other coastal waters around Europe, e.g. in the Tyrrhenian, Aegean and North Seas. Mucilage can affect marine ecosystems by massive development of aggregates that cover large areas, and it can seriously affect fisheries and tourism. Despite the fact that extensive literature on laboratory and field studies of mucilages is available, little is known about the triggering factors (Vollenweider \& Rinaldi 1995).
A mucilage aggregate is defined as an anomalous accumulation of organic matter, produced by various marine organisms under specific climatic and trophic conditions (Vollenweider \& Rinaldi 1995, Innamorati et al. 2001, Mecozzi et al. 2001). For example, hot springs and summers following mild winters with reduced rates of oceanic currents and wave motion, which result in anoxic conditions throughout the water column, have been linked to recent occurrences of mucilage in the Adriatic Sea (Vollenweider \& Rinaldi 1995, Thornton et al. 1999, Degobbis et al. 2000).

The macroaggregates of the northern Adriatic are mostly composed of water-soluble heteropolysaccharides and longer polymethylene chains attached (in 
decreasing order) to the monosaccharide units of glucose, fructose, mannose, galactose, fucose, arabinose, ribose and xylose. This suggests that polysaccharides in Adriatic macroaggregates originate primarily from phytoplankton exudates and structural polysaccharides, which are thought to be similar in composition to phytoplankton mucus (Kovac et al. 1998).

Diatoms are the major producers of mucilaginous material (Stachowitsch et al. 1990, Innamorati et al. 2001), and some species (especially pennate diatoms) are adhesive and flocculate in the absence of particulate mucus (Kiørboe \& Hansen 1993, Passow 2002). Diatom blooms are frequently terminated by mass aggregation of cells into large, rapidly sinking aggregates, which may attach to sediments. In some cases, benthic species predominate in the mucus (Zavodnik 1977), while in others cases pelagic or tychopelagic diatoms dominate (Fanuko et al. 1989). Skeletonema costatum is a bloom species reported to be a major extracellular polysaccharide producer.

Baldi et al. (1997), demonstrated that most diatoms in mucilage are lysed and release large amounts of particulate polysaccharides that are otherwise stored as intracellular carbon. These polysaccharides, as well as cell exudates, enter the marine carbon cycle of the Adriatic Sea. Baldi et al. (1997) suggested that diatom lysis is induced by biological factors such as viral and/or bacterial infection, or chemical factors such as anoxia. Recently, Ciglenečki et al. (2000) suggested a very important role for sulfur species in diatom lysis, and in the formation and stability of mucus aggregates in the Adriatic Sea.

In this study, we investigated the influence of anoxic conditions on mucopolysaccharide transformation in phytoplankton aggregates predominantly composed of benthic diatoms. Since anoxic conditions are associated with high concentrations of reduced sulfur species (produced by anaerobic respiration of sulfate-reducing bacteria), benthic diatom aggregates were experimentally exposed to different sulfide concentrations. The samples were incubated under anoxic conditions for up to $1 \mathrm{mo}$, with or without the addition of $10^{-4}$ and $10^{-3}$ mol $l^{-1}$ sulfide. In the same samples, the interaction between sulfide and organic matter as well as the formation of high molecular sulfopolymers was observed over a shorter period (10 d) at room temperature. Our aim was to study how intracellular particulate polysaccharides released from degraded diatoms after interaction with sulfide aggregate into layers and filaments to form gel-like compounds.

\section{MATERIALS AND METHODS}

Marine diatom culture. A sample of seawater was collected with a Niskin bottle from $30 \mathrm{~m}$ depth (near the bottom) seaward of the Lagoon of Venice in spring 2000 for the isolation of benthic marine diatoms; 11 of seawater was filtered through a $0.45 \mu \mathrm{m}$ nitrocellulose membrane (Millipore), and incubated in $\mathrm{f} / 2$ medium (Tomas 1996) containing $75 \mathrm{mg} \mathrm{NaNO}, 5 \mathrm{mg}$ $\mathrm{NaH}_{2} \mathrm{PO}_{4} \cdot \mathrm{H}_{2} \mathrm{O}$ and $30 \mathrm{mg} \mathrm{NaSiO} \cdot 9 \mathrm{H}_{2} \mathrm{O} \mathrm{l}^{-1}$ as major nutrients, as well as trace metals and vitamins. Mixed diatom cultures were incubated at room temperature under dim light (30 to $40 \mu \mathrm{mol} \mathrm{m} \mathrm{m}^{-2} \mathrm{~s}^{-1}$ ) and transferred each month into $50 \mathrm{ml}$ of fresh $\mathrm{f} / 2$ medium. Cell aggregates were observed in the enriched culture $(\sim 1 \times$

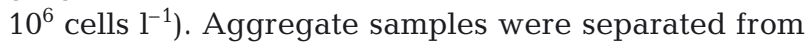
the supernatant (hereafter referred to as ambient water) with macropipettes. The same separation procedure was used in the case of natural mucilage samples. Identification of diatoms was made by microscope (Olympus Model 55) and phase-contrast optics, following descriptions in Round et al. (1990) and Tomas (1996).

Mucilage sampling. During the spring and summer months of 2002, mucilage formation was observed on several occasions in the Adriatic Sea. Mucilage samples were collected with a large syringe from different depths at offshore stations in the northern Adriatic by SCUBA. The aggregates, together with the ambient seawater, were stored in dark glass bottles at $4^{\circ} \mathrm{C}$ during transfer to the laboratory for further analysis.

Determination of diatom polysaccharides by lectin. Samples of the mixed diatom culture were used to determine the nature of released polysaccharides by incubating specimens with $25 \mu \mathrm{g} \mathrm{ml}^{-1}$ Con-A (Sigma) conjugated with fluoresceine isothiocyanate (FITC), a lectin from Concanavalia ensiformis, which specifically binds glucose and mannose residues. The methods have been tested on natural mucilage samples (Baldi et al. 1997). Digital images were obtained with a microscope-mounted camera in transmission and epifluorescence modes. The fluorescence pattern of the lectin was compared with that of natural mucilage sampled in the year 2002. To control sugar-specificity by Con-A, Lectin UEA-1 conjugated with fluorescein from Ulex europeus was used to determine fucose distribution (a minor sugar present in natural mucilage samples; Baldi et al. 1997).

Solutions of carrageenan. The structure of polysaccharide 1 -carrageenan consists of alternating copolymers of beta $(1 \rightarrow 3)$ D-galactose and beta $(1 \rightarrow 4)-3,6$ anhydro-D-galactose. This type of carrageenan has a sulfur content of $7.01 \%$ and produces flexible gels. Stock solutions of 1 -carrageenans (Sigma) were prepared in Milli-Q water and all chemicals were of analytical reagent grade.

Determination of reduced sulfur species (RSS). RSS in enriched diatom cultures and in seawater mucilage 
(aggregates, and ambient waters) were determined by cathodic stripping voltammetry (phase-sensitive alternating current voltammetry, PSACV, and linear sweep voltammetry, LSV; Ciglenečki \& Ćosović 1996, 1997). Measurements were performed with a $\mu$-Autolab (Electrochemical Instruments, Eco Chemie) connected to a 663 VA stand (Metrohm), with an SMDE (static mercury drop electrode) as the working electrode. The reference electrode was an $\mathrm{Ag} / \mathrm{AgCl}$ (3 $\mathrm{M} \mathrm{KCl}$ ) electrode connected to the solution via an electrolyte bridge, and a platinum electrode served as the auxiliary electrode. PSACV (in phase mode, $\varphi=0$ ) was performed at a frequency of $75 \mathrm{~Hz}$, an $\mathrm{AC}$ amplitude of $10 \mathrm{mV}$, and a potential scan rate of $10 \mathrm{mV} \mathrm{s}^{-1}$. LSV was run with a scan rate of $100 \mathrm{mV} \mathrm{s}^{-1}$.

Electrochemical determination of sulfur species is based on the reaction between sulfur and the mercury electrode. After accumulation of RSS on the electrode surface with stirring at the deposition potential $E=$ $-0.20 \mathrm{~V}$ (vs $\mathrm{Ag} / \mathrm{AgCl}$ ), we ran potential scans in the negative direction (up to $E=-1.00 \mathrm{~V}$ vs $\mathrm{Ag} / \mathrm{AgCl}$ ) and HgS reduction peaks, characteristic of many RSS, were recorded (Luther et al. 1985, Ciglenečki \& Ćosović 1996). The same method, modified by changing the deposition potential from $E=-0.20$ to $E=-0.40 \mathrm{~V}$ was used for distinguishing inorganic from organic sulfur species at the $\mathrm{Hg}$ electrode, following the method of Krznarić et al. 2001. Deposition at a potential $E=$ $-0.40 \mathrm{~V}$ would mainly yield a reduction peak, due to inorganic sulfur species $\left(\mathrm{S}^{0}, \mathrm{~S}^{2-}, \mathrm{S}_{\mathrm{x}}{ }^{2-}\right)$, while deposition around $E=-0.20 \mathrm{~V}$ would result in the sum of both organic and inorganic sulfur species.

Constant-current chronopotentiometric stripping analysis (CPSA) producing the 'presodium' catalytic currents at the hanging mercury drop electrode (HMDE) (based on the Brdička reaction: Heyrovsky \& Kuta 1965) was performed for detection of thiol groups in the polysaccharides of the enriched diatom cultures and seawater mucilage; constant-current CPSA produces well-resolved current peaks, 'presodium' currents, at HMDE that are characteristic of proteins and other compounds with $-\mathrm{SH}$ and $-\mathrm{NH}_{2}$ groups (Tomschik et al. 1998, 1999, Mader et al. 2001). The measurements were made with a PGSTAT 20 analyzer (Eco Chemie) connected to a 3-electrode cell consisting of HMDE as the working electrode, an $\mathrm{Ag} / \mathrm{AgCl}(3 \mathrm{M} \mathrm{KCl})$ as the reference electrode, and platinum wire as the auxiliary electrode. Accumulation of the catalytically active compound at the HMDE polarized to a potential $E=-0.60 \mathrm{~V}$ was achieved by stirring the solution for $60 \mathrm{~s}$ (accumulation time, $t_{\mathrm{a}}$ ). After a quiescent period of $10 \mathrm{~s}$, a constant stripping current of $I=-5 \mu \mathrm{A}$ intensity was passed through the electrolytic circuit, and constant-current CPSA curves were recorded.
Electrochemical measurements were carried out in a de-areated electrolyte solution containing $0.55 \mathrm{M}$ $\mathrm{NaCl}$, or in natural seawater samples.

Surface-active substances (SAS). SAS were determined with phase-sensitive AC voltammetry (Ćosović \& Vojvodic 1998). This electrochemical method measures the capacitive current (i.e. the current arising from adsorption processes, measured out-of-phase with the applied potential) separately from the faradaic current (originating from redox processes, measured in-phase with the applied potential). Out-of-phase measurements have found wide application in the study of organic substances with surface-active properties in marine and freshwater systems (Ćosović \& Vojvodić 1998).

The decrease in the capacitive current in the presence of surface-active organic material below the value for pure electrolyte indicates the amount of this material adsorbed onto the electrode (Jehring 1974), and can be expressed quantitatively by an equivalent amount of selected SAS, e.g. Triton-X-100. The shape of the voltammetric curves recorded (i.e. current vs potential) is characteristic of the substance investigated.

The experiments were performed with an HMDE in a 3-electrode cell connected to a commercial electrochemical instrument (Metrohm E 506). For quantitative determination, we used the calibration curve of the nonionic SAS, Triton-X-100. Natural mucilage samples were measured within $24 \mathrm{~h}$, after dilution in a $0.55 \mathrm{M} \mathrm{NaCl}$ electrolyte solution. Prior to measurements, samples were thoroughly homogenized by stirring.

Dissolved organic carbon (DOC). DOC measurements were performed with high-temperature catalytic oxidation (Shimadzu TOC-500). Fresh samples of ambient water were filtered through a $0.7 \mu \mathrm{m}$ Whatman $\mathrm{GF} / \mathrm{F}$ filter, poisoned with $\mathrm{HgCl}_{2}$, and stored in the dark at room temperature. The ambient water of the cultivated diatom macroaggregates was decanted from the aggregates with microsyringes, and was further treated in the same way as the natural seawater samples.

Incubation. Enriched diatom cultures were incubated under 2 anoxic conditions: (1) with addition of between $10^{-4}$ and $10^{-3} \mathrm{~mol} \mathrm{l}^{-1}$ sulfide, and (2) without addition of sulfide. Both experiments were performed in dim light at room temperature for a period of up to 1 mo. Incubations were in $50 \mathrm{ml}$ silanized vials sealed with aluminum caps with Teflon septa. Before incubation, all samples were purged with $\mathrm{N}_{2}$ to prevent oxidation of the sulfide. Incubated samples were investigated for possible incorporation of sulfide into polysaccharide molecules. In samples with added sulfide, the decrease in the additional (inorganic, free) sulfide 
due to its presumed incorporation into the polysaccharide aggregates, and the increase in formed organic sulfur species were monitored electrochemically as described above.

\section{RESULTS}

\section{Incubation experiment}

Microscopy

Benthic diatoms predominated in the enriched mixed cultures: Cylindrotheca closterium, Diploneis crabro, Gyrosigma sp., Navicula arenaria, Psammodictyon sp. and planktonic Chaetoceros sp. (Fig. 1). Fresh cultures had intact cells (Fig. 1A) which actively reproduced (Fig. 1B). After 1 mo incubation with sulfide, the diatom culture turned white in color and produced a gelatinous matrix, and the diatom cells vacuolated (Fig. 1C,D). In the sulfide-treated culture, bacteria predominated, while diatoms lost their pigmentation and extruded polysaccharide (Fig. 2A-D) due to cell lysis, not cell exudation. All these cells were dead and the major source of the polysaccharide was the intracellular carbon storage material extruded by the diatoms.

\section{Reduced sulfur species in diatom cultures}

Chemical interaction between sulfide and molecules of polysaccharides in the enriched culture was con-
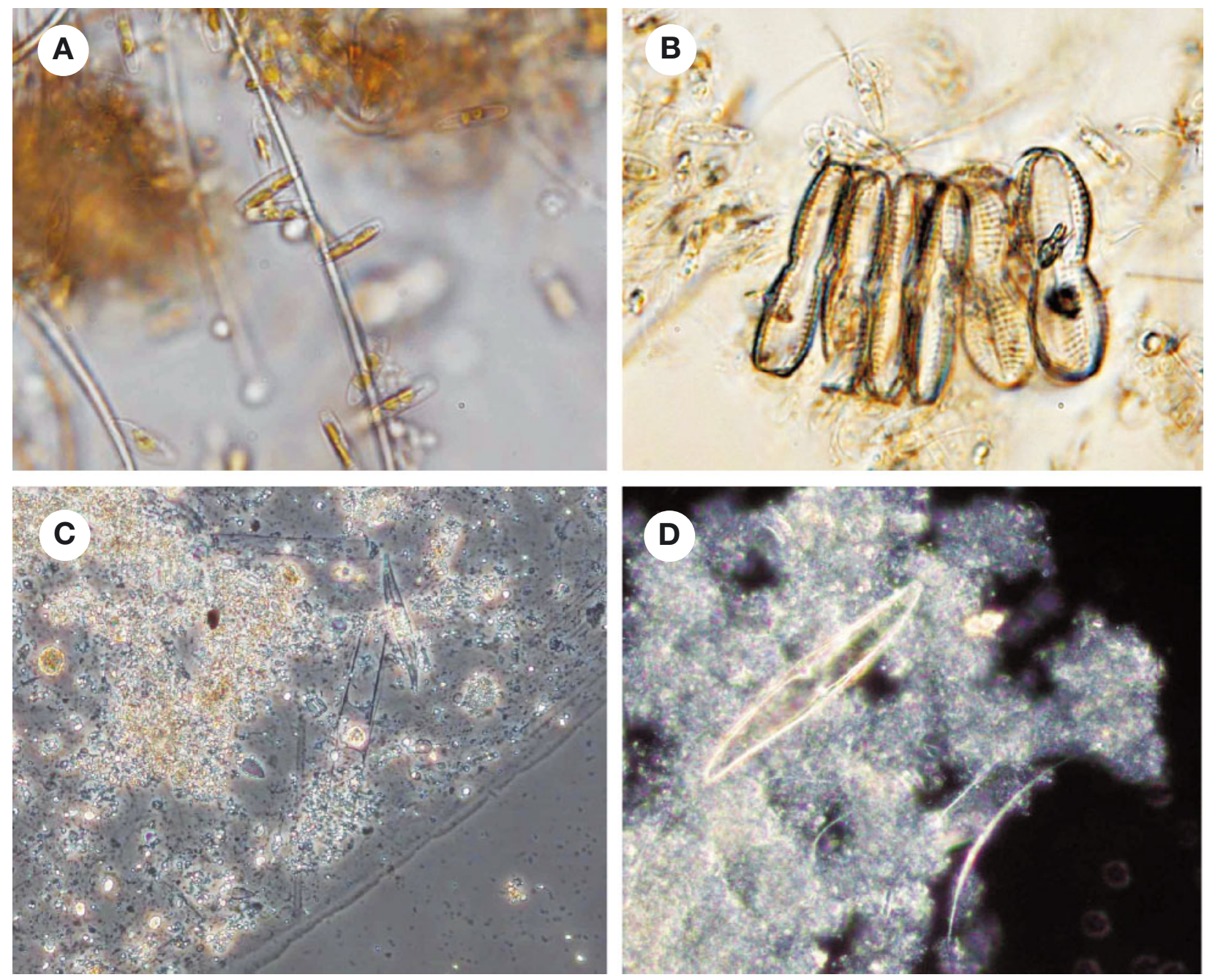

Fig. 1. Microscopic phase-contrast images of fresh diatom cultures in f/2 medium, incubated under dim light at room temperature: (A) Navicula arenaria with large photosynthetic apparatus; (B) reproducing Diploneis crabro surrounded by Navicula arenaria. Diatom cultures under anoxic conditions: (C) exopolysaccharidic materials (translucent particles) and vacoulated diatoms, including Gyrosigma sp., Cylindrotheca sp. and Hemialus sp.; (D) detail of Gyrosigma sp. in polysaccharide matrix. A-C, ×1000; $\mathrm{D}, \times 2000$ 

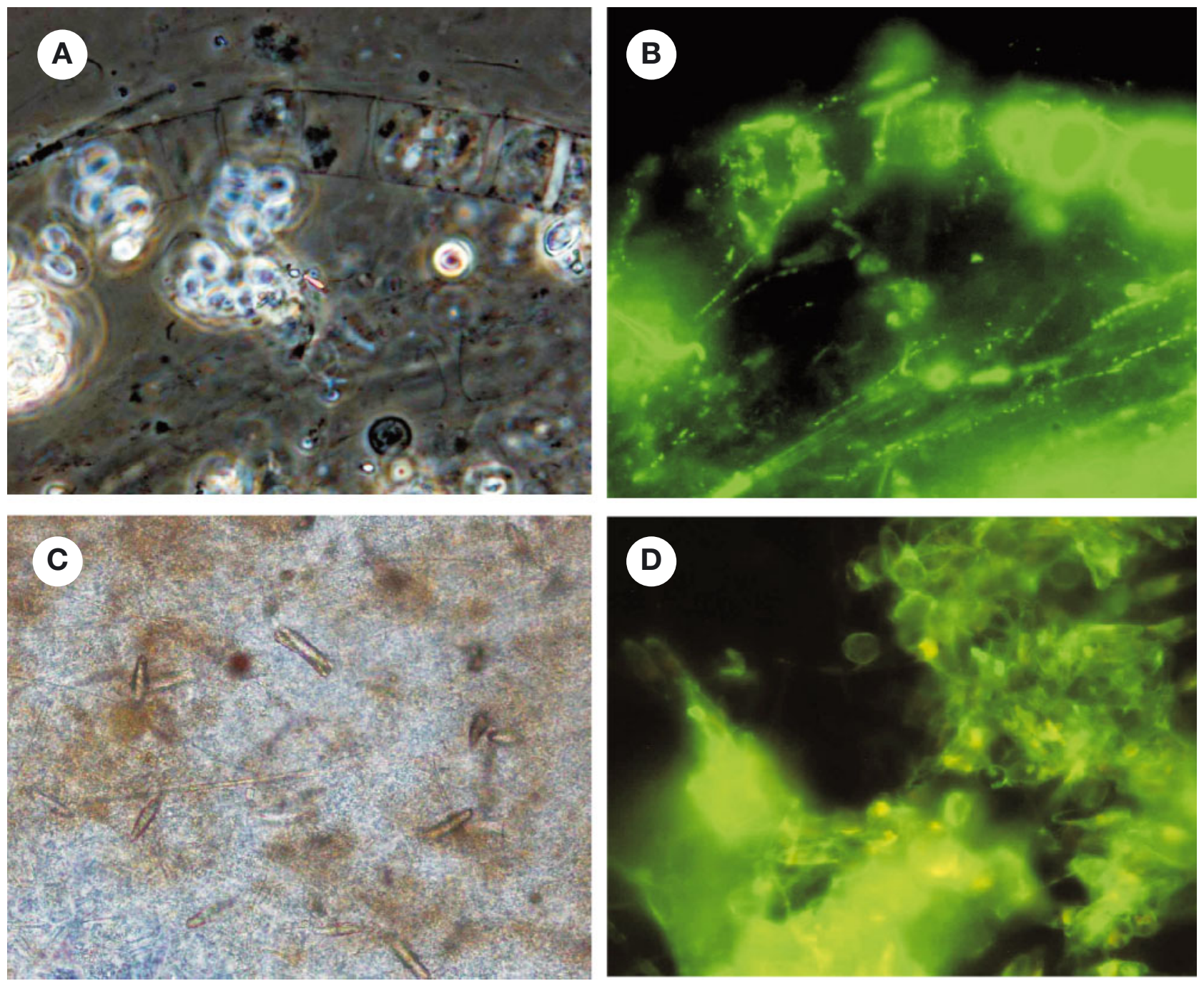

Fig. 2. (A) Phase-contrast image of diatom culture in $\mathrm{f} / 2$ medium under anoxic conditions, showing highly vacuolated dead Chaetoceros sp. (B) Same culture, with Con-A-FITC-positive polysaccharide extruding from cell. (C) Navicula arenaria embedded in polysaccharide matrix in phase-contrast. (D) Polysaccharide matrix imaged by Con-A-FITC, showing vacuolated frustules of Navicula arenaria. $\times 1000$

firmed by voltammetry and by the $\mathrm{HgS}$ voltammetric reduction peak at a potential $E$ $=-0.47 \mathrm{~V}$ vs Ag/AgCl (Fig. 3). A similar but less pronounced voltammetric peak was observed in the culture exposed to anoxic conditions for 1 mo without external addition of sulfide.

To verify the type of RSS (organic or inorganic), deposition at different starting potentials was performed (Krznarić et al. 2001). As shown for Sample 4 (see Table 1) in Fig. 3 (Line 3), no voltammetric peak was apparent for deposition at a potential $E=-0.40 \mathrm{~V}$, whereas for deposition at a potential $E=$ $-0.20 \mathrm{~V}$, an RSS peak at $E=-0.47 \mathrm{~V}$ was observed (Fig. 3: Lines 1 \& 2). Hence, this
Table 1. Concentration of surface-active substances (SAS), dissolved organic carbon (DOC) and reduced sulfur species (RSS) in mucus aggregates and ambient water of enriched cultures of mixed benthic diatoms. nd: below detection limit; (-): not measured

\begin{tabular}{|llccc|}
\hline Sample & & $\begin{array}{c}\text { SAS } \\
\left(\mathrm{mg} \mathrm{l}^{-1}\right)\end{array}$ & $\begin{array}{c}\text { DOC } \\
\left(\mathrm{mg} \mathrm{l}^{-1}\right)\end{array}$ & $\begin{array}{c}\text { RSS } \\
\left(\mathrm{nmol} \mathrm{l}^{-1}\right)\end{array}$ \\
\hline 1: Fresh & Aggregate & 0.35 & - & nd \\
& Ambient water & 0.59 & 7.17 & nd \\
2: Anoxic (1 mo) & Aggregate & 18.00 & - & 81 \\
& Ambient water & 18.25 & 27.00 & nd \\
3: With $10^{-3} \mathrm{~mol} \mathrm{~S}^{2-} \mathrm{l}^{-1}$ & Aggregate & 10.25 & - & 162 \\
$(10 \mathrm{~d})$ & Ambient water & 12.50 & - & $\mathrm{nd}$ \\
4: With $10^{-4} \mathrm{~mol} \mathrm{~S}^{2-} \mathrm{l}^{-1}$ & Aggregate & 17.50 & - & 937 \\
$(1 \mathrm{mo})$ & Ambient water & 19.56 & 40.00 & $\mathrm{nd}$ \\
\hline
\end{tabular}




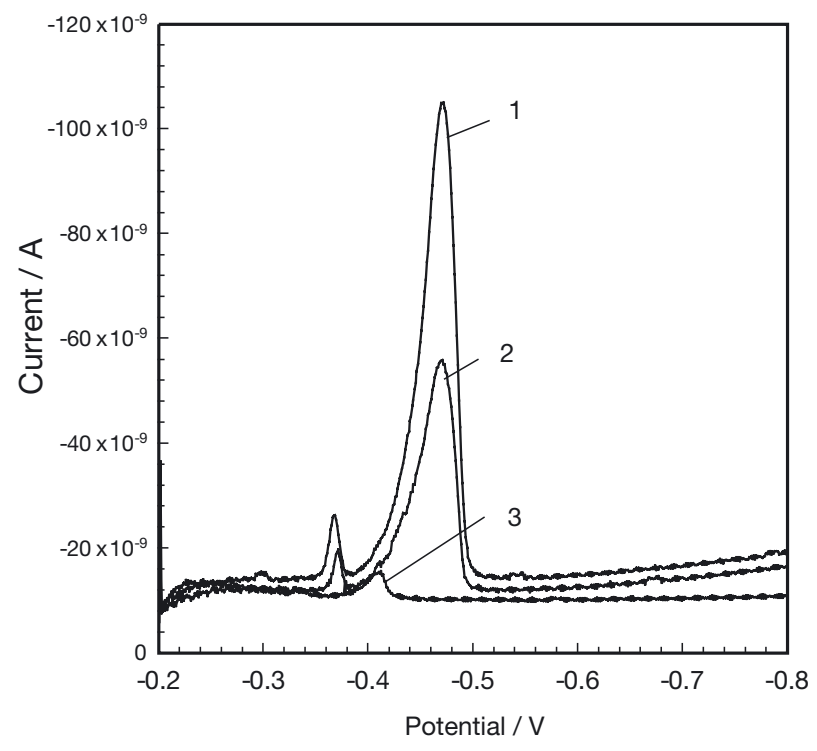

Fig. 3. Linear sweep voltammograms (LSV) of organosulfur species in aggregates of benthic diatom enriched cultures after 1 mo incubation with $10^{-4} \mathrm{~mol}^{-1}$ sulfide under steady anoxic conditions. Accumulation achieved by stirring at deposition potential $E=-0.20 \mathrm{~V}$ for (1) $t_{\mathrm{a}}=120 \mathrm{~s}$ and (2) $t_{\mathrm{a}}=60 \mathrm{~s}$, and at potential $E=-0.40 \mathrm{~V}$ for (3) $t_{\mathrm{a}}=60 \mathrm{~s}$; $t_{\mathrm{a}}$ : accumulation time

voltammetric peak could be ascribed to the presence of organosulfur species alone. Sample 3 (Table 1), with a $10 \mathrm{~d}$ incubation period, also contained free (inorganic) sulfide. Added (free) sulfide thus decreased during

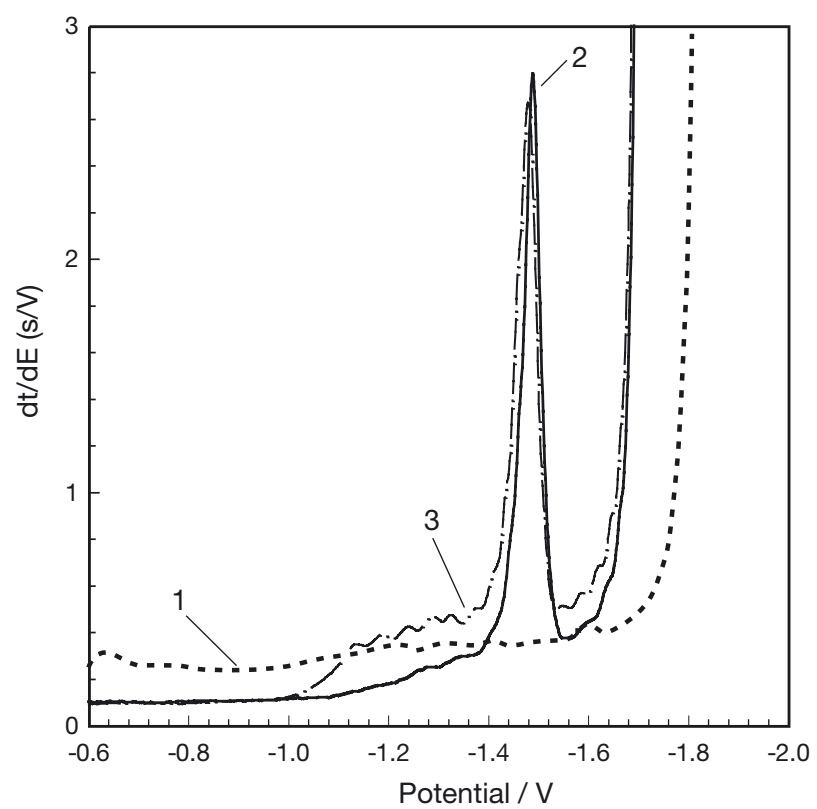

Fig. 4. Constant-current chronopotentiometric stripping ana-

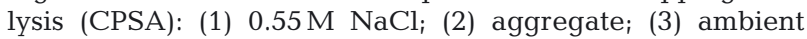
water of benthic diatom enriched cultures (dilution 2/25) after 1 mo exposure to anoxic conditions. Accumulation achieved by stirring, at potential $E=-0.60 \mathrm{~V}$; accumulation time: $t_{\mathrm{a}}=$ $60 \mathrm{~s}$; constant-stripping current: $I=-5 \mu \mathrm{A}$ incubation; the concentration of organosulfur species (RSS) increased concomitantly in the aggregates, but not in the ambient water (Table 1).

Constant-current CPSA was used to detect $-\mathrm{SH}$ groups in polysaccharides of diatom cultures exposed to anoxic conditions and sulfide. A sharp peak was obtained at a potential $E=-1.50 \mathrm{~V}$ for both aggregates and ambient water (Fig. 4), indicating the presence of a compound which is causing catalytic evolution of hydrogen: in this case, the compound with built-in - SH group formed during the incubation experiment. This likewise proves the interaction between added sulfide and organic matter from the diatom culture. A similar peak was obtained with a solution of sulfated polysaccharides (1-carrageenan) (Fig. 5). Carrageenan is a polysaccharide compound containing galactopyranosic units and built-in S-groups, and shows an in-phase reduction voltammetric peak at $E=-1.40 \mathrm{~V}$ (Plavšić \&Ćosović 1998, Ciglenečki et al. 2000).

\section{Surface-active substances and DOC}

In untreated samples, concentrations of SAS were $0.35 \mathrm{mg} \mathrm{l}^{-1}$ in the aggregates and $0.59 \mathrm{mg} \mathrm{l}^{-1}$ in ambient water (Table 1). In samples treated with sulfide, surfactant activity increased (up to $20 \mathrm{mg} \mathrm{l}^{-1}$ Triton-X100 equivalents), in aggregates and ambient water. SAS levels increased with incubation time and with longer exposure to anoxic conditions (Table 1). These

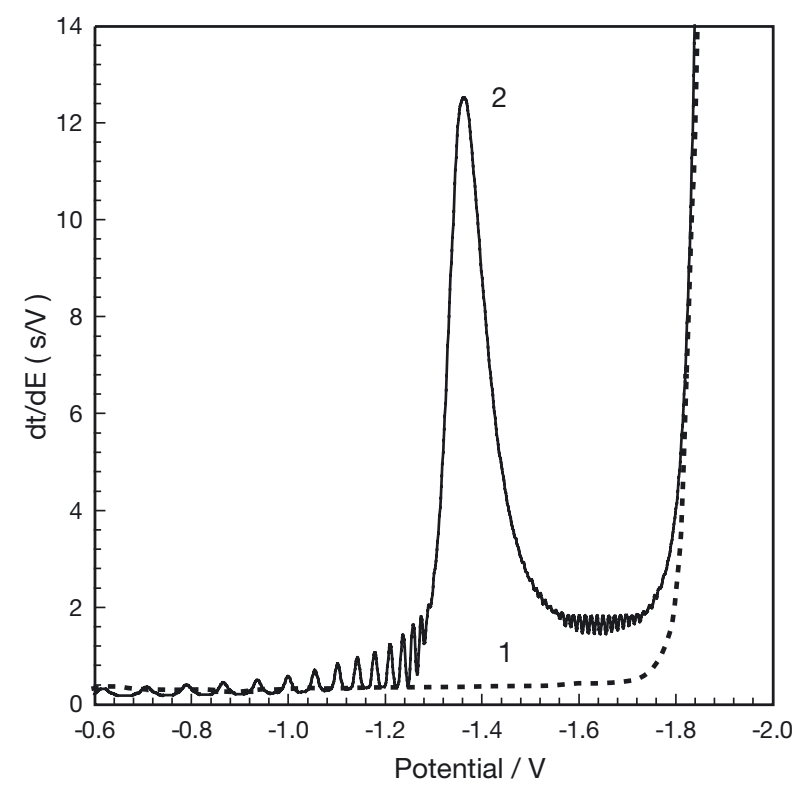

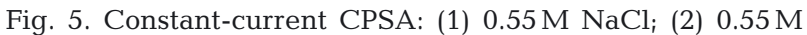
$\mathrm{NaCl}$ with $300 \mathrm{mg} \mathrm{l}^{-1}$ carrageenan. Accumulation achieved by stirring; potential $E=-0.60 \mathrm{~V}$; accumulation time: $t_{\mathrm{a}}=60 \mathrm{~s}$; constant-stripping current: $I=-5 \mu \mathrm{A}$ 

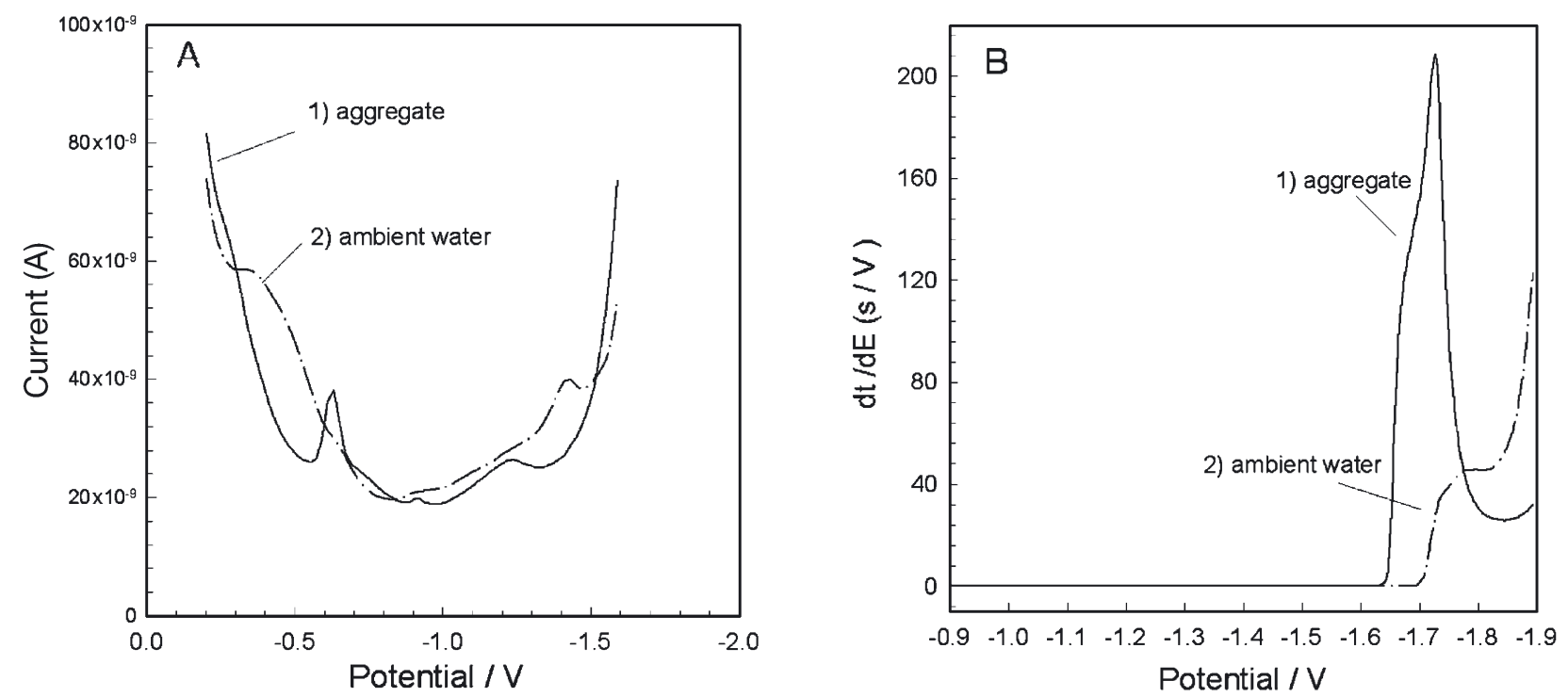

Fig. 6. (A) AC voltammograms of natural mucilage collected from the northern Adriatic Sea in June 2002; (B) constant-current CPSA curves of aggregate (dilution $12.5 / 50 \mathrm{ml}$ ) and ambient water of natural mucilage sample in (A). Accumulation achieved by stirring at potential $E=-0.90 \mathrm{~V}$; accumulation time: $t_{\mathrm{a}}=60 \mathrm{~s}$; constant-stripping current: $I=-5 \mu \mathrm{A}$

changes in surfactant activity may be due to structural changes in organic matter (predominantly in polysaccharides); we do not have direct evidence of the formation of sulfopolysaccharide, a surface-active material, but our results point to this conclusion.

This is supported by the fractionation experiment with ambient water of a natural mucilage sample collected from the Adriatic Sea in August 1997 (Sample 1: Table 2). The organic matter was separated into hydrophobic and hydrophilic fractions by sorption onto XAD-8 resin (Vojvodić et al. 1994), and organosulfur species were detected exclusively in the hydrophilic fraction composed predominantly of carbohydrates. This hydrophilic fraction represented $25.4 \%$ of the total surfactant activity, $67.3 \%$ of the dissolved organic carbon, and $100 \%$ of the RSS content of the ambient water.

In the ambient water of the samples treated with sulfide, concentrations of DOC increased by several times (Table 1).

\section{Natural mucilage samples}

During the late spring and summer months of 2002, several mucilage occurrences were recorded in the Adriatic Sea, and some of the mucilage samples contained several species of benthic pennate diatoms, regardless of sampling depth.
Fig. 6 shows in-phase AC voltammetric and constant-current CPSA curves for both aggregate and ambient water from the mucilage sample collected in June 2002 (Sample 3: Table 2). RSS occurred only in the aggregate, not in the ambient water (Fig, 6, top: peak at $E=-0.60 \mathrm{~V}$ ). If we disregard the wide small peak at $E \approx-1.24 \mathrm{~V}$, which could be associated with the peak at $E=-1.40 \mathrm{~V}$, the second, more negative peak at $E=-1.40 \mathrm{~V}$ in the ambient water was missing from the aggregate. According to the electrochemical patterns, the RSS type in this aggregate sample corresponds to organosulfur species at concentrations of $18 \times 10^{-9} \mathrm{~mol}$ $\mathrm{l}^{-1}$ (Table 2). For the aggregate, constant-current CPSA curves displayed a peak at $E=-1.70 \mathrm{~V}$; this peak was less pronounced in ambient seawater (Fig. 6B). No

Table 2. Concentration of surface-active substances (SAS), dissolved organic carbon (DOC) and reduced sulfur species (RSS) in mucus aggregates and ambient water of selected natural samples. (f): filtered; (nf): not filtered; nd: below detection limit; (-): not measured

\begin{tabular}{|c|c|c|c|c|c|}
\hline Sample & & $\begin{array}{l}\text { Depth } \\
\text { (m) }\end{array}$ & $\begin{array}{c}\text { SAS } \\
\left(\mathrm{mg} \mathrm{l}^{-1}\right)\end{array}$ & $\begin{array}{c}\mathrm{DOC} \\
\left(\mathrm{mg} \mathrm{l}^{-1}\right)\end{array}$ & $\begin{array}{c}\text { RSS } \\
\left(\mathrm{nmol} \mathrm{l}^{-1}\right)\end{array}$ \\
\hline 1: 13 Aug 1997 & $\begin{array}{l}\text { Aggregate } \\
\text { Ambient water }\end{array}$ & 0.5 & $\begin{array}{c}13.7 \\
2.4 \text { (nf) } 2.1 \text { (f) }\end{array}$ & $\begin{array}{c}- \\
25.0\end{array}$ & $\begin{array}{l}\text { nd } \\
16\end{array}$ \\
\hline 2: 17 Jun 2000 & $\begin{array}{l}\text { Aggregate } \\
\text { Ambient water }\end{array}$ & 12 & $\begin{array}{c}10.3 \\
1.4(\mathrm{nf})\end{array}$ & - & $\begin{array}{l}30 \\
\text { nd }\end{array}$ \\
\hline 3: 20 Jun 2002 & $\begin{array}{l}\text { Aggregate } \\
\text { Ambient water }\end{array}$ & 8 & $\begin{array}{c}5.0 \\
0.3(\mathrm{nf})\end{array}$ & $\begin{array}{c}- \\
3.5\end{array}$ & $\begin{array}{l}18 \\
\text { nd }\end{array}$ \\
\hline 4: 8 Jul 2002 & $\begin{array}{l}\text { Aggregate } \\
\text { Ambient water }\end{array}$ & 10 & $\begin{array}{c}3.1 \\
-\end{array}$ & $\begin{array}{c}- \\
6.8\end{array}$ & $\begin{array}{l}190 \\
\text { nd }\end{array}$ \\
\hline
\end{tabular}




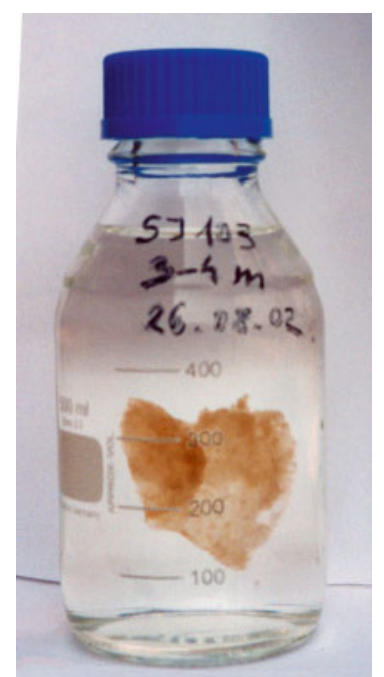

Fig. 7. Polysaccharide-based mucilage collected from northern Adriatic in August 2002 at depth of 3 to $4 \mathrm{~m}$ constant-current CPSA peak was detected in seawater samples of low organic content or in pure $0.55 \mathrm{M} \mathrm{NaCl}$ solution.

Polysaccharide-based mucilage produced by diatoms in the northern Adriatic Sea in August 2002 is shown in Figs. 7 \& 8 .

\section{DISCUSSION}

In an enriched mixture of phytoplanktonic/benthic algae (predominantly pennate diatoms, which are very common in the Adriatic Sea and the Venice Lagoon; Facca et al. 2002) enriched with $10^{-4}$ and $10^{-3} \mathrm{~mol} \mathrm{l}^{-1}$ of $\mathrm{Na}_{2} \mathrm{~S}$ and incubated at room temperature and in dim light, the effect of sulfide was reflected in macroand microscopic changes. These relatively high sulfide concentrations are typical of anoxic marine environments (Luther et al. 1991, Ciglenečki et al. 1996, 1998).
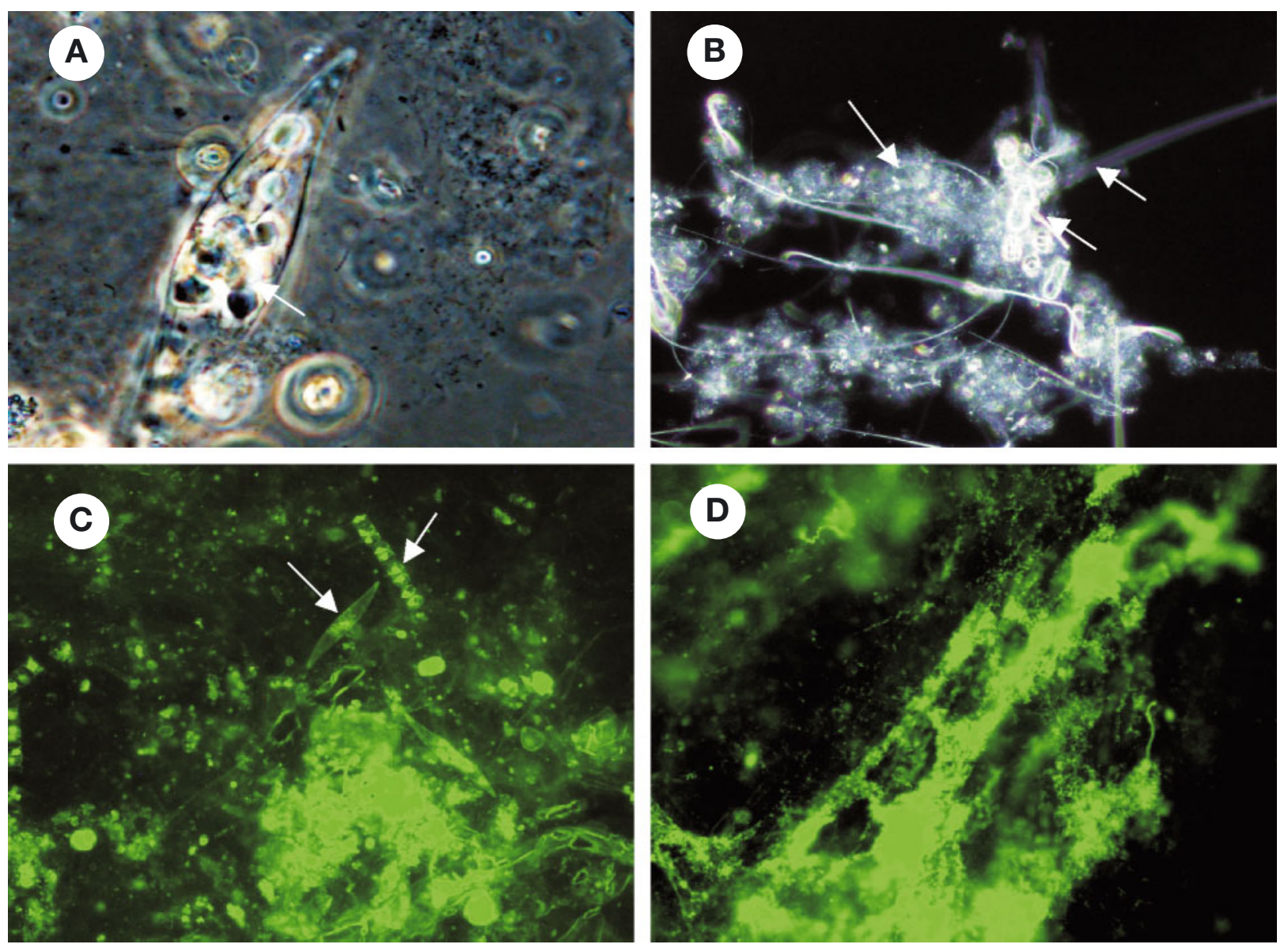

Fig. 8. Mucilage sampled in August 2002. (A) Gyrosigma sp. containing carbon storage material (arrow) thought to be responsible for massive mucilage formation after cell degradation. (B) Vacuolated diatoms, including Cylindrotheca sp. and Psamodictium sp. aggregates (arrows) in mucilagenous material. (C) Polysaccharide diatom aggregates. (D) Large polysaccharide aggregate in 'mature' mucilage sample without diatoms and colonized by heterotrophic bacteria. A,C: Phase-contrast photographs; B,D: fluorescence microscopy using Con-A-FITC. A, $\times 2000$; B-D, $\times 1000$ 
Several hours after the addition of sulfide, diatom cell aggregates in the enriched cultures became denser and more rigid. The changes were visible to the naked eye.

Formation of organosulfur species, changes in the concentration and physico-chemical properties of the organic matter followed by increased surfactant activity, and degradation of diatoms followed by cell lysis and release of large amounts of polysaccharides, were observed by electrochemical measurements, DOC measurements and microscopy.

Electrochemical measurements revealed the presence of RSS in all incubated samples, including the diatom-enriched culture exposed to anoxic conditions without added sulfide. Since bacteria were not excluded from the diatom culture, the presence of RSS in Sample 2 (Table 1) was probably associated with bacterial sulfate reduction.

In seawater of $\mathrm{pH}=8.0 \pm 0.2, \mathrm{HgS}$ reduction usually takes place at an electrode potential near $E=-0.68 \mathrm{~V}$ vs Ag/AgCl (Luther et al. 1985); however, the position of this peak shifts with fluctuations in $\mathrm{pH}$ (Redinha et al. 1997). Our sample solution was not buffered, and the $\mathrm{pH}$ after incubation with sulfide was $\sim 6.0$; consequently, the RSS peak was recorded at $E=-0.47 \mathrm{~V}$ (Fig. 3). However, such changes in $\mathrm{pH}$ do not influence the peak height, i.e. measured RSS concentration (Krznarić et al. 2001).

A speciation study of RSS revealed the presence of organosulfur species. A combination of 3 electrochemical methods (LSV, PSACV and constant-current CPSA) identified these as mainly sulfopolysaccharides. The organosulfur species were detected in aggregates only, with higher concentrations in samples exposed to longer incubation periods, i.e. in samples where a longer interaction between sulfide and organic matter was possible. In these samples, the highest increase in surfactant activity was observed over longer incubation periods, in the same proportion in both the aggregates and the ambient water. The increase in surfactant activity by 2 orders of magnitude was partly due to the transformation of organic matter and the formation of predominantly sulfopolysaccharides, which exhibit a high surfactant activity and are mainly concentrated in aggregate samples. Increases in surfactant activity at lower percentages (10 to $20 \%$ ) have also been found in solutions of carrageenans incubated with $10^{-6} \mathrm{~mol} \mathrm{l}^{-1}$ $\mathrm{Na}_{2} \mathrm{~S}$ for $24 \mathrm{~h}$ (Ciglenečki et al. 2000). Of all polysaccharides investigated (dextrans, xanthan, carrageenans), the electrochemical pattern of natural mucilage samples was closest to that of the sulfated polysaccharides (carrageenans). Zou et al. (1998) showed that transparent exopolymer particles (TEP), which play an important role for ocean particle aggregation and floc formation (Passow 2002, Prieto et al. 2002), are enriched in adhesive, surface-active sulfate polysaccharides.
However, recent results of Gašparović \& Ćosović (2003) obtained with an electrochemical probe indicated an important contribution of hydrophobic lipidlike material to increased surfactant activity of Adriatic mucilage samples.

The large increase in DOC concentration in ambient water of all incubated samples could be associated with both intensified diatom-cell polysaccharide secretion caused by stress due to sulfide or anoxic poisoning, and cell lysis. Anomalies in climatic and trophic conditions, i.e. environmental stress arising from (e.g.) fluctuations in temperature, nutrients, pollutants or oxic-anoxic conditions are possible causes of mucilage formation (Vollenweider \& Rinaldi 1995, Mecozzi et al. 2001). In the northern Adriatic Sea, mucilage has indeed observed in connection with reduced water circulation, water-column stratification and decreasing oxygen saturation in bottom waters (Degobbis et al. 2000).

Natural mucus aggregates are mainly composed of aliphatic components and polysaccharides bonded through carboxylic and amide groups, and organosilicon compounds (Kovac et al. 2002). Macroaggregate composition and stability vary as mucus ages. The agglomeration and stability of macroaggregates are probably enhanced by interactions with RSS and with entrapped particles of calcite, quartz and clay minerals (Ciglenečki et al. 2000, Kovac et al. 2002).

The similarity in microscopic and electrochemical observations between the incubated diatom culture and natural mucus aggregates indicates that both have the same pathway of mucilage formation. Our incubation results confirmed that: (1) anoxic marine microzones developing through reduced flux of oxygen into benthic diatom aggregates (which colonize the sediment surface in spring), and/or marine snow could be an important source of RSS (Shanks \& Reeder 1993); (2) upon exposure to sulfide, diatoms lose their photosynthetic activity, become vacuolated, lose intracellular material such as stored carbon particles, and decompose; (3) polysaccharide polymer structures are extruded after interaction with sulfide, increasing the stability of the mucus aggregates.

Sulfide poisoning is one of the possible causes of cell lysis. Particulate polysaccharides released from the cells interact with sulfide. Secondary transformation arises from various microbial activities and/or chemical interactions, which may remove key molecules (Cesaro et al. 1992). The transition from crystalline to soluble polysaccharide forms indicates key changes in the molecular structure. For example, cation/sugar bridges may be destroyed, and the polysaccharides may lose their crystalline form and become more soluble, subsequently aggregating into layers and filaments to form the gel-like mucilage repeatedly observed in the Adriatic Sea (Baldi et al. 1997). 


\section{CONCLUSIONS}

Our sulfide poisoning experiments and exposure to anoxic conditions of predominantly benthic diatom macroaggregates mimicked one aspect of unfavorable environmental conditions; they resulted in intensified cell polysaccharide secretion and cell lysis, as in natural mucilage samples. We confirmed strong interactions between organic matter and sulfide, apparent as the formation of surface-active organosulfur species (sulfopolysaccharides). The increase in DOC concentration in the ambient water during the incubation experiment arose from intensified secretion of stressinduced cell polysaccharides, combined with cell lysis.

Acknowledgements. The authors thank Dr. P. Noack and G. Socal of the CNR Institute Biologia del Mare, Venezia for collecting samples of bottom marine water. The authors also thank the crew and the scientific staff of the Croatian RV 'Vila Velebita' for their technical assistance. Thanks are extended to Dr. C. A. Facca for helping in diatom classification, and to F. Zecchini for preparation of microscopic samples and help in shipping the samples. We gratefully acknowledge the valuable suggestions and comments of anonymous reviewers and the copy editor. This research was partly supported by the Croatian Ministry of Science and Technology and by a grant from the Italian Ministry of Public Affairs.

\section{LITERATURE CITED}

Baldi F, Minacci A, Saliot A, Mejanelle L, Mozetić P, Turk V, Malej A (1997) Cell lyses and release of particulate polysaccharides in extensive marine mucilage assessed by lipid biomarkers and molecular probes. Mar Ecol Prog Ser 153:45-58

Cesaro A, Gamini A, Navarini L (1992) Supramolecular structure of microbial polysaccharides in solution: from chain conformation to rheological properties. Polymer 33: 4001-4008

Ciglenečki I, Ćosović B (1996) Electrochemical study of sulfur species in seawater and marine phytoplankton cultures. Mar Chem 52:87-97

Ciglenečki I, Ćosović B (1997) Electrochemical determination of thiosulfate in seawater in the presence of elemental sulfur and sulfide. Electroanalysis 9:1-7

Ciglenečki I, Kodba Z, Ćosović B (1996) Sulfur species in Rogoznica Lake. Mar Chem 53:101-111

Ciglenečki I, Kodba Z, Viličić D, Ćosović B (1998) Seasonal variation of anoxic conditions in the Rogoznica Lake. Croat Chem Acta 71:217-232

Ciglenečki I, Ćosović B, Vojvodić V, Plavšić M, Furić K, Minacci A, Baldi F (2000) The role of reduced sulfur species in the coalescence of polysaccharides in the Adriatic Sea. Mar Chem 71:233-249

Cosović B, Vojvodić V (1998) Voltammetric analysis of surface-active substances in natural seawater. Electroanalysis 10:429-434

Degobbis D, Precali R, Ivančić I, Smodlaka N, Fuks D, Kveder $\mathrm{S}$ (2000) Long-term changes in the northern Adriatic ecosystem related to anthropogenic eutrophication. Int J Environ Pollut 13:495-533

Facca CA, Sfriso G, Socal G (2002) Changes in abundance and composition of phytoplankton and microphytobenthos due to increased sediment fluxes in the Venice Lagoon. Estuar Coast Shelf Sci 54:773-792

Fanuko N, Rode J, Drašler K (1989) Microflora from the Adriatic mucous aggregations. Biol Vestn 37:27-33

Gašparović B, Ćosović B (2003) Surface-active properties of organic matter in the North Adriatic Sea. Estuar Coast Shelf Sci 56:(in press)

Heyrovský J, Kuta J (1965) Principles of polarography. Czechoslovak Academy of Sciences, Prague

Innamorati M, Nuccio C, Massi L, Mori G, Melley A (2001) Mucilages and climatic changes in the Tyrrhenian Sea. Aquat Conserv: Mar Freshw Ecosyst 11:289-298

Jehring H (1974) Electrosorption-Analyse mit WechselstromPolarographie. Akademie-Verlag, Berlin

Kiørboe T, Hansen JLS (1993) Phytoplankton aggregate formation: observations of patterns and mechanisms of cell sticking and the significance of exopolymeric material. J Plankton Res 15:993-1018

Kovac N, Faganeli J, Sket B, Bajt O (1998) Characterization of macroaggregates and photodegradation of their water soluble fraction. Org Geochem 29:1623-1634

Kovac N, Bajt O, Faganeli J, Sket B, Orel B (2002) Study of macroaggregate composition using FT-IR and ${ }^{1} \mathrm{H}-\mathrm{NMR}$ spectroscopy. Mar Chem 78:205-215

Krznarić D, Ciglenečki I, Ćosović B (2001) Voltammetric investigations of 2-dimethylarsinyl-ethanol sulfide in $\mathrm{NaCl}$ and seawater. Anal Chim Acta 431:269-278

Luther GW, Giblin AE, Varsolona R (1985) Polarographic analysis of sulfur species in marine porewaters. Limnol Oceanogr 30:727-736

Luther GW, Church TM, Powell D (1991) Sulfur speciation and sulfide oxidation in the water column of the Black Sea. Deep Sea Res 38:S1121-S1137

Mader P, Vesela V, Dorčak V, Heyrovsky M (2001) The 'presodium' hydrogen evolution at the dropping mercury electrode catalysed by simple cysteine peptides. Collect Czech Chem Commun 66:397-410

Mecozzi M, Acquistucci R, Di Noto V, Pietrantonio E, Amici M, Cardarilli D (2001) Characterization of mucilage aggregates in Adriatic and Tyrrhenian Sea: structure similarities between mucilage samples and the insoluble fractions of marine humic substance. Chemosphere 44: $709-720$

Passow U (2002) Transparent exopolymer particles (TEP) in aquatic environments. Prog Oceanogr 55:287-333

Plavšić M, Ćosović B (1998) Adsorption of carrageenans on mercury surface in sodium chloride solution and seawater. Croat Chem Acta 71:233-243

Prieto L, Ruiz J, Echevarria F, Garcia CM, Bartual A, Galvez JA, Corzo A, Macias D (2002) Scales and processes in the aggregation of diatom blooms: high time resolution and wide size range records in a mesocosm study. Deep-Sea Res I 49:1233-1253

Redinha JS, Paliteiro C, Pereira JLC (1997) Determination of sulfide by square-wave polarography. Anal Chim Acta 351:115-125

Round FE, Crawford RM, Mann DG (1990) The diatoms. Biology and morphology of the genera. Cambridge University Press, Cambridge, UK

Shanks AL, Reeder ML (1993) Reducing microzones and sulfide production in marine snow. Mar Ecol Prog Ser 96:43-47

Stachowitsch M, Fanuko N, Richter M (1990) Mucus aggregates in the Adriatic Sea: an overview of stages and occurrence. PSZN I: Mar Ecol 11:327-350

Thornton DCO, Santillo D, Thake B (1999) Prediction of spo- 
radic mucilaginous algal blooms in the northern Adriatic Sea. Mar Pollut Bull 38:891-898

Tomas CR (1996) Identifying marine diatoms. Academic Press, San Diego Tomschik M, Havran L, Fojta M, Palecek E (1998) Constant-current chronopotentiometric stripping analysis of bioactive peptides at mercury and carbon electrodes. Electroanalysis 10:403-409

Tomschik M, Jelen F, Havran L, Trnkova L, Nielsen PE, Palecek E (1999) Reduction and oxidation of peptide nucleic acid and DNA at mercury and carbon electrodes. J Electroanal Chem 476:71-80

Vojvodić V, Ćosović B, Mirić V (1994) Fractionation of

Editorial responsibility: Otto Kinne (Editor),

Oldendorf/Luhe, Germany surface-active substances on the XAD-8 resins. Part I. Mixtures of model substances. Anal Chim Acta 295: $73-83$

Vollenweider RA, Rinaldi A (eds) (1995) Marine mucilage. Proc Int Workshop Mar Mucilage Phenomena. Sci Total Environ 165 (special issue)

Zavodnik D (1977) Benthic communities in the Adriatic Sea: reflects of pollution. Thalassia Jugosl 13:413-422

Zhou J, Mopper K, Passow U (1998) The role of surface-active carbohydrates in the formation of transparent exopolymer particles by bubble adsorption of seawater. Limnol Oceanogr 43:1860-1871

Submitted: March 3, 2003; Accepted: August 19, 2003

Proofs received from author(s): October 30, 2003 